\title{
WHEN KINGDOMS ARE KINGDOMS NO MORE: A SOCIAL-SCIENTIFIC READING OF THE MUSTARD SEED (LK 13:18-19) $^{1}$
}

\section{ABSTRACT}

This article presents a social-scientific reading of the parable of the Mustard Seed. It is argued that the parable is not a parable of growth or contrast, and does not allude to the Old Testament. In taking the specifics of the Lukan version of the parable seriously, it is proposed that the Mustard Seed questions religious respectability as understood by the kingdom of the Temple, and undermines imperial interests of the kingdom of Rome.

\section{INTRODUCTORY REMARKS}

The history of the interpretation of the Mustard Seed shows that the parable is dominantly interpreted as a parable of growth or contrast, with possible allusions to imagery from the Old Testament. Because of these interpretational lenses, the parable depicts the kingdom of God as an (apocalyptical) eschatological entity: the kingdom starts as something insignificant but becomes something large. In this article this "stock" interpretation of the Mustard Seed is questioned by employing a socialscientific reading of Luke 13:18-19 which is considered as the version closest to the earliest Jesus tradition. It is argued that two aspects of Luke's version of the parable, namely that the mustard seed is planted in a garden which then turns into a tree, were part of the original parable, and are critical for the understanding of the Mustard Seed in a 27-30

1 This contribution is dedicated to Hermie van Zyl, in recognition of the contribution his study of the gospel of Luke made in a national and international context.

Prof. Ernest van Eck, Department of New Testament Studies, University of Pretoria. E-mail address: ernst.vaneck@up.ac.za 
CE Galilean or Palestinian context - the context in which Jesus first told the parable.

\section{HISTORY OF INTERPRETATION}

The earliest interpretations of the Mustard Seed are the allegorical interpretations of the Church Fathers. In these interpretations the mustard seed represents the word (the gospel) ${ }^{2}$ or Jesus, ${ }^{3}$ the land (or garden) represents the world, ${ }^{4}$ the tree the church or heaven, ${ }^{5}$ and the birds represent divine angels and lofty souls. ${ }^{6}$ The theological interpretations of Luther and Calvin - who, with John Chrysostom, Thomas Aquinas and John Maldonatus attempted to break away from the allegorical interpretations of the parables - did not succeed in deconstructing the dominant (allegorical) interpretation of the parable. In Luther's interpretation the mustard seed is equated with Christ and the believers with the branches that spread from the mustard bush (see Pelikan, Oswald \& Lehmann 1987:88), and for Calvin the parable serves as an encouragement to those who would shrink back in offence at the lowly beginnings of the gospel (see Torrance \& Torrance 1972:79-80).

Since Jülicher's ground-breaking contribution to parable interpretation in the early twentieth-century, most parable scholars have moved away from an allegorical interpretation of the parables, focusing on the meaning of the parables in their literary contexts. The more recent history of interpretation

2 See Clemens of Alexandria (150-215 CE) in The Paedagogus, Book I, Tertullian (c. 160-225 CE) in Against Marcion, Book IV, and John Chrysostom (347-407 CE) in his Homily 21 on Hebrews. See also Apostolic Constitutions, Book III (written in Syria about $380 \mathrm{CE}$ ), in which the mustard seed is described as "the word with a fiery nature". Minority opinions are those of Basil the Great (329379 CE) and Jerome (347-420 CE). Basil, in his De Spiritu Sancto, compares the insignificant mustard seed with the testimony of the martyrs, and Jerome sees in the mustard seed an analogy for the church (Letter 66).

3 Irenaeus (c. 115-202 CE), in Fragments from the Lost Writings of Irenaeus equates the mustard seed with Jesus Christ who, after his resurrection, sprung up like a big tree that became the shelter for the nations, while Augustine of Hippo (354-430 CE) in Contra Faustum, Book XII describes the seed as Christ that takes over the whole world.

4 See Tertullian (Against Marcion, Book IM) and John Chrysostom (Homily 21 on Hebrews; Homily 46 on Matthew).

5 This is inter alia the interpretation of Clemens of Alexandria (Fragments from the Hypotyposes, $V$ and Gregory of Nazianzus (c. 329-389/390 CE) in his Oration 42.

6 See Clemens of Alexandria, in his Fragments from the Hypotyposes V. 
of the Mustard Seed is indicative of this shift in focus. Except for a few allegorical interpretations, ${ }^{7}$ most interpreters focus on the meaning of the Mustard Seed in its literary contexts in the Synoptics (Mk 4:30-32, Mt 13:3132 or Lk 13:18-19), and is unanimous regarding the meaning of the parable: the Mustard Seed is a "parable of growth" or a "parable of contrast". Snodgrass' interpretation can be seen as representative of this "received view" of the supposed meaning of the Mustard Seed: The parable depicts the presence of the kingdom in Jesus' ministry and Jesus' expectation of the certain full revelation of the kingdom to come (Snodgrass 2008:222) "like a mustard seed God's kingdom starts as something insignificant but becomes something quite large" (Snodgrass 2008:223).

This emphasis on growth or contrast was introduced by Arnot in 1872 (see Lockyer 1963:185-186), and since has become part of the dominant interpretation of the Mustard Seed. With these two features of the parable as interpretive lens, interpreters focus on some or other aspect of growth or contrast in search of the meaning of the parable: Some emphasise the growth-aspect of the parable,$^{8}$ while others emphasise the contrast between small beginning and large end. ${ }^{9}$ As a subset of one of these two interpretations, some scholars - when emphasising the growth-aspect of the parable - focus on the significance of the coming of the kingdom in due course (the parable's end) ${ }^{10}$ or the kingdom's orderly development, ${ }^{11}$ while

7 A few examples of modern allegorical interpretations of the Mustard seed are the following: the birds in the trees refer to the Gentiles (Marcus 1986:214), the nations of the world (Bugge 1903:34-35) or the devil's messengers as part of Satan's tactics referred to in Matthew 13:19 (Scharlemann 1979:346); the sowing of the seed is the proclamation (sowing) of Jesus or God to the people (land; see Heil 1993:283-285; Keach 1978:244; Marcus 1986:213-216; 2000:329, 331; Scharlemann 1979:346); and the smallness of the seed refers to the small beginning of the church (Morgan 1953:48-49).

8 See Brouwer (1946:148), Buttrick (2000:75), Dahl (1976:147), Gäbel (2007:333), Perkins (1981:85-88) and Westermann (1990:186).

9 See the interpretations of Brouwer (1946:148), Carter (2006:181-201), Donahue (1988:37), France (2002:216), Jones (1995:327), Kümmel (1957:128-131), Lang (1955:78), Mussner (1960:128-30), Reid (2001:103), Schippers (1962:87-93), Snodgrass (2008:221) and Stein (1981:94-95).

10 See, for example, Beasley-Murray (1986:123-125), Blomberg (2004:122-124), Capon (1985:117), Davies and Allison (1997:417), Dodd (1961:190-191), Fuchs (1960:291-292), Gundry (1993:230), Hultgren (2000:395, 401), Jüngel (1962:139174), Kendall (2006:34-41), Kistemaker (1980:51), Marcus (1986:113), Schweitzer (1963:34), Smith (1937:120), Weiss (1900:69) and Wierzbicka (2001:278-287).

11 See Baarslag (1940:429), Boucher (1981:67-69), Bruce (1886), Gladden (1883:34), Groenewald (1973:32-38), Hunter (1971:57; 1976:45-46) and Rauschenbusch (1950:51-52). 
others - who emphasise the contrast-aspect - see as focus of the parable its small beginnings. ${ }^{12}$ Because of the dominance of this emphasis, readings of the parable that do not focus on growth or contrast are exceptional, and considered a minority reading (see e.g., Crossan 1992:50; Lambrecht 1983:101; Manson 1949:73; Oakman 2008:111-117; Scott 1989:387). ${ }^{13}$

The second aspect that dominates the interpretation of the Mustard Seed was introduced by Funk in 1973, nearly a hundred years later than Arnot's emphasis on growth and contrast (see Funk 1973:3-9; 2006:113115; Funk, Hoover \& The Jesus Seminar 1993:59-60). Funk argues that Jesus, in the original version of the parable, employed the surprising figure of the mustard seed as a figure of speech for the kingdom. His audience would probably have expected the kingdom to be compared to something great, not something small. As the original parable was passed on in the oral tradition, it came under the influence of two symbols from the Old Testament: the mighty cedar of Lebanon - in the prophetic tradition - as a metaphor for a towering empire (that of Israel under Saul, David and Solomon; see Ezk 17:22-23) and that of the apocalyptic tree in Daniel 4:12 and 20-22. This is the reason, Funk argues, why the Synoptic writers changed the image from a plant to a tree. From this perspective, the mustard seed is a parody (satire or burlesque) of the cedar of Lebanon in Ezekiel and the apocalyptic image of Daniel. Funk, off course, was not the first scholar that identified possible Old Testament imagery in the Mustard Seed, ${ }^{14}$ but the first to propose that the "tree" in the Matthean- and Lukan versions, as a later addition to the original parable, is a "burlesque" on the two named Old Testament images (contra Jeremias and Dodd). Since Funk's reading of the parable, several scholars have followed suit in their interpretation of the Mustard Seed (see, e.g., Blomberg 2004:122124; Buttrick 2000:77; Perkins 1981:85-88; Reid 2001:104-106;15 Scott

12 For this emphasis in the interpretation of the parable, see especially Brouwer (1964:148), Dibelius (1971:255-258) and Wills (2011:68).

13 A reading that indeed can be considered as a minority reading is that of Cotter (1992:45-48), who opines that the smallness of the seed symbolically refers to the secrecy of the mission of the Q-community.

14 Baarslag (1940:425), Dodd (1961:191), Bultmann (1963:179-205 and Jeremias (1972:149), for example, have seen in the birds dwelling in the tree/plant some Old Testament imaginary present in Isaiah 10:33-11:1 and 14:4-20, Zachariah 11:1-2, Judges 9:15, Ezekiel 17:23; 31:6, Daniel 4:12, 21 [LXX] and Psalm 37:3536 and 104:12.

15 Taking Funk's interpretation as point of departure, Reid (2001:104-106) interprets the image of the tree in the parable as follows: Rather than thinking of the coming reign of God as a majestic cedar tree that is imported from Lebanon, Jesus uses the image of a lowly garden herb. God's realm is not a dominating empire, but its power erupts out of its weakness. The mustard plant 
2001:35-46; Wenham 1989:53; Wills 2011:6816). There are, however, scholars who argue against the Old Testament imagery as a later addition to the parable (see, e.g., Davies \& Allison 1997:420; Hultgren 2000:396; Marcus 1986:204), while others deny that there is any allusion to the Old Testament in the parable. ${ }^{17}$

The first remark that can be made, based on the above described history of interpretation of the Mustard Seed, is that the parable is, with almost no exception, interpreted through an eschatological lens. The parable's history of interpretation indicates that it does not really matter if the parable is about growth and not contrast (or vice versa), or does refer to the Old Testament or not; in essence, all these readings suggest that the Mustard Seed it is about the delay of the parousia, about a kingdom still to come, a kingdom only to be consummated in future. ${ }^{18}$ Dodd (1961:191), for example, argues that the parable has nothing to do with growth or contrast, but the capacity of the shrub to afford shelter to the birds of the heavens. As such, the parable announces that the time has come when the multitudes of Israel, perhaps even of the Gentiles, will flock to the shelter of the tree. Jeremias (1972:149) is also clear on the so-called eschatological intent of the parable: Just as certain as that a tall shrub can grow from

cannot be eradicated once it infests a field. The parable thus states that God's realm will always overcome antagonistic forces.

16 Funk's interpretation of the parable can also clearly be seen in Wills' (2011:68) interpretation when he states: The parable is "satirical and humorous, and highly suggestive: the kingdom is like a scrubby invasive bush!"

17 These scholars argue that the wording of the parable is not close enough to any text in the Old Testament to identify one text to which allusion is made (see, e.g., Crossan 1973:47; Liebenberg 2000:289-290; Snodgrass 2008:224). Crossan (1992:46), for example, see these allusions as not explicit or appropriate; if it refers to a tree, it can only refer to Psalm 104:12, which refer only to God's loving providence (see also Donahue 1988:37).

18 The focus on growth and Old Testament imagery in the history of the interpretation of the Mustard Seed is most probably the reason why the Thomasine version of the parable has not really received attention by parable scholars. Even in the cases where the Thomas-version is deemed to be the most original, the focus quickly shift to the Synoptic versions (see, e.g., Crossan 1992:47; Donahue 1988:36; Funk et al. 1993:194). When attended to, Thomas 20:1-4 is seen as a Gnosticized version of the parable in the Synoptics. Crossan (1992:49), for example, sees Thomas' "tilled earth" (Thom 20:4) as a "gnostic admonition", while Hultgren (2000:395) argues that the mustard seed represents the spark of light, the enlightenment that comes to the Gnostic, and the tilled ground refers to the readiness of the Gnostic to receive it. Recent studies, however, have shown that Thomas is not "Gnostic", but can rather be typified as one of the earliest attempts to read the Jesus tradition through the lens of Middle-Platonism (see Patterson, Bethge \& Robinson 2011:47). 
a small seed, the few followers of Jesus will swell into a mighty host of the people of God in the messianic age, embracing Gentiles. ${ }^{19}$ As can be seen from the history of the parable's interpretation, Jeremias and Dodd's eschatological emphasis in its interpretation is representative of the lens through which the parable is read: The coming of the birds to make their nests in the shade of the large plant is interpreted as an eschatological image of the incorporation of the Gentiles into the people of God, an image that is sometimes, but not always, based on references to the Old Testament. ${ }^{20}$

Snodgrass (2008:222) is thus correct when he states:

\begin{abstract}
Despite disagreement over details and over whether the focus is contrast or growth, there is a surprising agreement about the intent of the parable. Here, virtually unquestioned, we hear the voice of Jesus asserting a vital and central element of his eschatology, his understanding of what God was doing to set things right. Whatever else is debated, the parable pictures the presence of the kingdom in Jesus' own ministry, even if others do not recognize it, and Jesus' expectation of the certain full revelation of the kingdom to come.
\end{abstract}

The above quote from Snodgrass begs a second remark regarding the "surprising agreement about the intent of the parable": Is the supposed eschatological emphasis in the parable the voice of Jesus speaking in 27$30 \mathrm{CE}$ amongst the peasantry somewhere in rural Galilee or at the shores of the Sea of Galilee, or that of the Synoptics, or, for that matter, the voices of the (modern) interpreters of the parable?

Interestingly, one finds no reference to an eschatological kingdom in the interpretation of the parable by the few scholars who read the Mustard Seed in a constructed historical Jesus-context and not in its literary context in the Synoptics. In the Mustard Seed, according to Lambrecht

19 According to Jeremias (1972:147), the eschatological character of the parable is

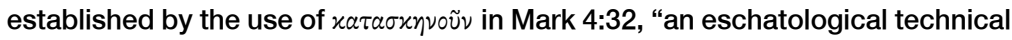
term for the incorporation of the Gentiles into the people of God" (see Joseph and Aseneth 15:7). There is, however, little evidence for this interpretation. As

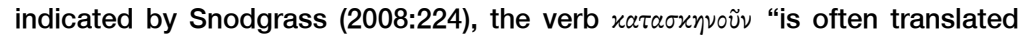
as 'nest' but merely means 'dwell'." See also Louw and Nida (1988:71), who translate $\alpha a \tau \alpha \sigma \varkappa \eta \nu 0 \tilde{\nu}$ as "to make a nest (or possibly to find shelter)".

20 See, for example Drury (1985:86), who sees the point of the parable as a reference to the eschatological arrival of the kingdom, and Wenham (1989:53), who states that the parable looks forward to the time when God's kingdom, inaugurated in Jesus' ministry, will appear. See also Kilgallen (2008:72), Boucher (1981:69), Fleddermann (1989:233-234) and Grässer (1960:141-143) as representative of the eschatological reading of the parable. 
(1983:101), Jesus reveals the nature of the kingdom of God, or, as typified by Manson (1949:73), God's present rule. Scott (1989:387), in his reading of the parable, focus inter alia on the planting of the mustard seed in a garden, which associates Jesus and a present kingdom with uncleanness (see below § 4.2). In the most extensive reading of the Mustard Seed as a parable of the historical Jesus, Oakman (2008:111-117) also presents a non-eschatological reading. In this reading the mustard seed is sown in a cultivated field, with other seed (because it is so small it cannot be seen), or seeds itself. The mustard seed grows fast and wild, and quickly overshadows the cultivated field and takes it over (the so-called the wildness of the Power; see Oakman 2012:140). The seed and birds thus are negative symbols in the parable:

As a metaphor for the reign of God, this 'weed' stands over against the basic arrangements of civilization. It threatens the foundation of the edifice in its threat to the cultivated field (Oakman 2008:116).

Jesus thus likens the kingdom to a harvest time weed. The presence of the weed makes it possible for the birds to roost and supply in their need for food. For the sown (the exploitative arrangements of Jesus' world as the basic arrangements of civilization), the weed (the kingdom) is no good; it simply takes over. Crossan (1991:278-279), in his most recent reading of the parable, follows Oakman's interpretation. The point of the parable is not the contrast between small beginnings and large endings, but that the seed tends to take over, tends to get out of control and tends to attract unwanted birds; the kingdom is thus like a pungent shrub with dangerous takeover properties.

The above history of interpretation of the Mustard Seed indicates that, contra Snodgrass, no "surprising agreement" exists in the interpretation of the parable. This is especially the case when one is interested in the meaning of the parable on the level of the historical Jesus, in so far it is possible to determine. One persistent problem in parable research, that is yet again clear from the history of the interpretation of the Mustard Seed, is the indiscriminate way in which the versions of the parables in the Synoptics (and Thomas) are frequently ascribed to "Jesus", and not, for example, the Jesus of Matthew or Luke. Moreover, "meanings" of the parables of Jesus are sometimes uncritically assumed as "the" meaning, while these "meanings" suggest certain values and convictions that are directly opposed to values and convictions of Jesus that can most probably linked to the earliest layer of the Jesus-tradition.

The latter remark touches the nerve of the history of the interpretation of the Mustard Seed. If one takes as point of departure that Jesus was eschatologically apocalyptic in orientation, the parable can be seen as a 
parable of growth or even contrast, and the birds that flock to the bush/tree can be understood as the future universal character of a kingdom to come. From this perspective, the parable begs an eschatological interpretation. If one, however, takes as point of departure the possibility that Jesus, in his parables, depicted the kingdom as a present reality, the Mustard Seed cannot be about growth or the contrast between "beginning;" and "end". ${ }^{21}$ Then, as Miller (2001:113) has indicated, the Mustard Seed rather leans toward a story that is a clever satire of "religious respectability", and, added to this, a story that undermines some of the exploitative measures as a result of the Roman occupation of first-century Palestine. From this perspective, the Mustard Seed is a story of how the kingdom of God subverts the kingdom of Caesar and the kingdom of the Temple.

To argue the latter, attention is first given to the different extant versions of the parable in an effort to determine the version of the parable that is most probably closest to the historical Jesus. Second, the social values (cultural scripts or social register) that were part of the repertoire of the teller and audience of the parable are discussed. The fact that the interpreter of the parable is not part of the social system that produced the parable, not only necessitates this discussion, but also at least guides an interpretation that is aware of ethnocentrism and anachronism. Flowing from this discussion, the parable is read by employing social-scientific criticism, and, finally, the question is asked if the parable can indeed be traced to the historical Jesus.

\section{VERSIONS AND INTEGRITY}

We have four extant versions of the Mustard Seed, namely Thomas 20:14, ${ }^{22}$ Mark 4:30-32, Matthew 13:31-32 and Luke 13:18-19. The Matthean and Lukan versions of the parable most probably stem from $Q(Q 13: 18-19) .{ }^{23}$

21 See Van Eck (2009:315-316), where he makes a case for this line of approach when one is interested in the parables as parables of Jesus in a 27-30 CE context, and not in their literary context in the Synoptics or in Thomas.

22 For Thomas 20, the English translation from Coptic by Funk (et al. 1993:471532 ) is used.

23 The verbal similarities shared by Matthew and Luke, that are not paralleled in Mark, indicate that these two versions most probably stem from $Q$. These

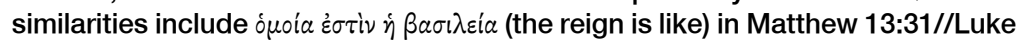
13:18, ôv $\lambda \alpha \beta \dot{\omega} \nu \alpha$ a $\nu \theta \rho \omega \pi \circ \varsigma$ (a man took) in Matthew 13:31//Luke 13:19 (not in Mark),

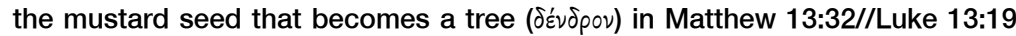

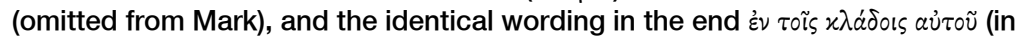
its branches) against Mark. Based on these similarities against Mark, several scholars is of the opinion that the Matthean and Lukan versions stem from $Q$ 
Some scholars argue that Mark is the earliest version of the parable (e.g., DuPont 1975:340-345; Jones 1999:84; Klauck 1978:210), others believe Thomas is the earliest (Crossan 1992:47; Donahue 1988:36; Funk et al. 1993:194), while a third group see $Q$ as representing the earliest version, best preserved by Luke (Dodd 1961:191; Fleddermann 1989:226; Hultgren 2000:400-401; Jülicher 1910:421; Luz 1990:231; Scott 1989:377). ${ }^{24}$ A fourth point of view is that all the extant versions are 'original', since Jesus told the parables more than once, especially parables of the kingdom like the Mustard Seed (Snodgrass 2008:222). ${ }^{25}$

A close reading of the four extant versions indicates that the similarities between the four versions are the kingdom that is compared to a mustard seed (implied in Thomas), and the birds ( $\tau \dot{\alpha} \pi \varepsilon \tau \varepsilon i v \alpha \dot{\alpha})$ that dwell in what the mustard seed turns into. For the rest, the four versions differ on almost every detail. In Mark, Matthew and Thomas the mustard seed is the smallest of all seeds. In Mark and Matthew the mustard seed turns into the largest of all garden plants. For Mark, the mustard seed is the smallest seed "on the earth" (not for Matthew), and in Matthew the largest of all garden plants is called a tree (not in Mark). In Thomas, the mustard seed simply grows into a large plant. Mark and Matthew thus have the "smallestlargest" comparison, and Thomas only the smallest (without the largest). Luke, interestingly, does not have the "smallest-largest" comparison in his version of the parable. The four versions also differ with regards to where, how and by whom the mustard seed is planted. In Thomas it simply falls (planted?) on prepared soil, in Mark it is planted in the earth ( $\dot{\varepsilon} \pi i \tilde{\eta} \varsigma \gamma \tilde{\eta} \varsigma)$,

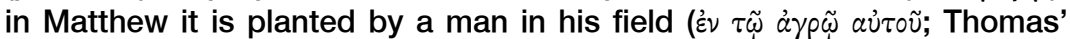
prepared soil?), and in Luke it is, like Matthew, planted by a man, but in

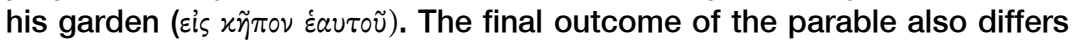
in the four versions. In Mark the mustard seed turns into the largest of all garden plants ( $\left.\mu \varepsilon \tilde{\zeta} \zeta o \nu \pi \alpha^{\prime} \nu \tau \omega \nu \tau \tilde{\omega} \nu \lambda \alpha \chi \alpha \dot{\alpha} \nu \omega \nu\right)$, emphasising its big branches and

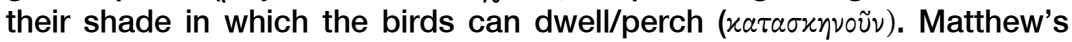

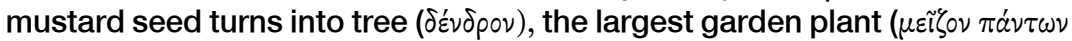
$\tau \tilde{\omega} \nu \lambda \alpha \chi \alpha \dot{\alpha}(\omega \nu)$, with branches in which the birds dwell. In Luke the mustard

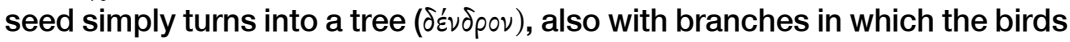

(see Bultmann 1963:172; Donahue 1988:36; Hultgren 2000:393; Kloppenborg 1988:148-151; Lambrecht 1983:99; Manson 1949:123; Polag 1979:66; Streeter 1930:291).

24 Some scholars also attempted to reconstruct the "original parable" (see Fleddermann 1989:217-214; Hultgren 2000:397-398), without any clear-cut or convincing results.

25 This point of view, which in essence negates Redaktionsgeschichte in principle, is supported by almost no parable scholar, and should be considered as a minority opinion. 
dwell. In Thomas, finally, the mustard seed turns into a large plant (not a garden plant), with no reference to its branches (as in the three other versions), emphasising not its shade (as in Mark), but the large plant used by the birds as shelter.

According to Snodgrass (2008:222; see also Lang 1955:186), these differences between the four versions are

interesting, but they - apart from the possible significance of the 'tree' - do not constitute a difference in meaning. The smallness of the seed is mentioned in Mark and Matthew and assumed in Luke, and whether it is sown in a field, the earth or a garden changes nothing in terms of the parable's intent. In the end there is not much significance to the variation in wording (Snodgrass 2008:222; emphasis added).

This remark of Snodgrass is surprisingly uncritical. Nowhere in Luke is the smallness of the seed assumed - it is simply not there, and only a possible deduction because the interpreter has three other versions for comparison. More important is the question whether the smallness of the seed was part of the earliest version of the parable, especially if one is interested in the intent of the parable in a 27-30 CE context. Moreover, as will be indicated below (see $\S 4.2$ ), a mustard seed sown in a field, the earth or a garden makes a serious difference in terms of the parable's intent. Fact of the matter is that the redactional activity of the evangelists is evident in the differences between the extant versions. Therefore, if one is interested to postulate - in as far it is possible - the earliest version of the parable, it is necessary to sift through the redactional activity that can be indicated in the extant versions. Only then one can postulate a version that is most probably the closest to the "original" parable Jesus told. The details of this version then can be used to postulate the possible intent Jesus had with the parable.

Let us start with the version in Mark 4:30-32. Mark's introduction to the

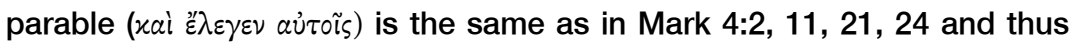
typically Markan. Mark's mustard seed is sown in the earth (i $\pi i$ in $\left.\gamma^{\prime} \gamma \tilde{\eta} \varsigma\right)$, which is also typically Markan (see Mk 4:1, 5, 8, 20, 26, 28, 32). Mark's description of the mustard seed as "the smallest of all seeds on the earth"

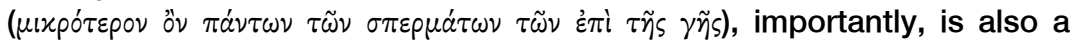
Markan redaction. Mark's description of the mustard seed as the smallest of all seeds is part of a literary construction that Donahue has coined as a "Markan insertion technique", whereby Mark makes an insertion into the (oral or pre-Markan) tradition he used and then repeats after it the phrase 
which preceded it (see Crossan 1992:46). ${ }^{26}$ This insight of Donahue is important for the interpretation of the parable; the reference to the mustard seed as the smallest of all seeds most probably was not part of the earliest version of the parable (see also Dodd 1961:191; Hultgren 2000:397). By implication, Mark's reference to the mustard seed as turning into the largest of all plants thus also was not part of the original parable. In short, Mark changed the parable of Jesus into a growth parable.

Some scholars view the Thomasine version as independent of the Synoptics (see, e.g., Hedrick 1994:250; Patterson 1993:27-28) because it does not have the problem with the "smallest and largest" of Mark and the shrub of Mark that turns into a tree in Q. Others believe that the Thomasine version is a dependent and edited version of the Mustard Seed in the Synoptics. ${ }^{27}$ The latter argument seems to be the case, especially when the Thomasine and Markan versions of the parable are compared. From a structural point of view, Thomas 20:1-4 has the same structure as Mark 4:30-32, except for the parenthesis in Mark 4:31-32a. Other similarities are the seed as the smallest seed (Mk 4:31//Thom 20:3), the use of "when" (" $\tau \alpha v)$ in Mark 4:32//Thomas 20:4, and the correspondence between "on prepared soil" (Thom 20:4) and "on the ground" (Mk 4:32; see Hultgren 2000:394-395). Interestingly, in Thomas the smallest seed (as in Mark) does not turn into the largest plant, but simply into a large plant. This difference and similarities between Thomas and Mark most probably indicate that Thomas 20:1-4 is a reworked version of Mark's version.

Turning to Q 13:18-19, Matthew 13:31-32 has conflated his source (Q) and Mark. Except for the typically Matthean introduction to the parable

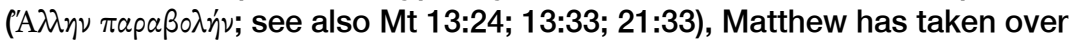

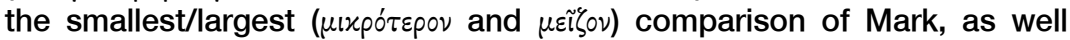
as Mark's reference to the largest plant as a garden plant $(\tau \tilde{\omega} \nu \lambda \alpha \chi \alpha \dot{\alpha} \nu \omega \nu)$. Distinctive of Matthew is that the seed is sown in a cultivated field $(\dot{\varepsilon} \nu \tau \tilde{\omega}$ $\dot{a} \gamma \rho \tilde{\varphi})$, but it has the tree of $Q^{28}$

The Lukan version of $Q$ 13:18-19 (Lk 13:18-19) is seen by most scholars as closest to the original parable of Jesus (see again above). The main

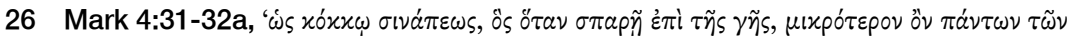

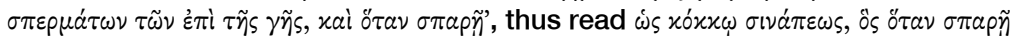
$\dot{\varepsilon} \pi \grave{\imath} \tau \tilde{\eta} \varsigma \gamma \tilde{\eta} \varsigma$ in the tradition Mark used. Some examples of this Markan technique are Mark 2:9b-11 and 10:47b-48b (see Crossan 1992:46). Perrin (1971:173-187) noted that Donahue identified forty seven instances of the "Markan insertion technique" in Mark (see Crossan 1992:46, n. 6).

27 See Hultgren (2000:394, n. 8) for the proponents of this view.

28 For other features of the Matthean redaction of the parable, see Hultgren (2000:399-400) and Jones (1995:323). 
reason for this point of view is that Luke is the only version that does not have any element of Mark's redactional "smallest and largest". The Q-version, it seems, had no element of growth as part of the parable. Like Matthew, Luke kept Q's seed that turns into a tree. Distinctive of Luke is that the seed is planted in a garden $(\kappa \tilde{\eta} \pi \circ v)$. The coming of the birds to the bush, tree or large plant for shelter or to perch in its shade - in Luke a tree in which the birds perch in its branches - should also be considered as part of the original parable. As referred to above, some scholars argue that that this image (Mk 4:32//Q 13:19 [Mt 13:32//Lk 13:32]//Thom 20:4) is a later addition to the original parable to facilitate the apocalyptic eschatological imagery, based on the Old Testament, of the incorporation of the Gentiles into the people of God (see, e.g., Funk 1973:3-9; Crossan 1992:48-49). Hultgren (2000:396) makes a strong case that this imagery was not added later, and should be seen as integral to the original parable: 1) the imagery belongs to the basic structure and content of the parable; 2) it is part of all four extant versions; and 3) no actual Old Testament text is quoted, "but only a rather elusive symbol derived from a number of texts is alluded to" (Hultgren 2000:396; see also Crossan 1992:48; Oakman 2007:113).

To summarize: The Markan version of the parable, used by Thomas, redactionally added the growth aspect to the Mustard Seed, and Matthew conflated Mark with the Q-parable (independent of Mark) and Mark, we independent, and Matthew conflated Mark with the Q-parable. The Lukanversion of $Q$ seems to be the closest to the original parable of Jesus. Below it will be argued that that the Lukan version of the Mustard Seed $(=Q)$, without the growth metaphor (smallest/largest), with the seed being planted in a garden that turns into a tree to which the birds flock, most probably goes back to the earliest Jesus tradition. Luke's version constitutes a definite difference in meaning of the parable, a meaning that has to do with the essence of what Jesus wanted to convey when he compared the kingdom of God with a mustard seed.

\section{A SOCIAL-SCIENTIFIC INTERPRETATION OF LUKE 13:18-19}

\subsection{Background information and social scripts}

The first hearers of the Mustard Seed were first-century peasants from Galilee who, in an advanced agrarian society, worked the land in an effort to make a living. These first hearers of the parable can be described as "emic listeners", that is, listeners to the parable from a native's point of view. By this is meant that the parable contained certain background information 
not known by the modern reader, and also evoked certain cultural norms or scripts (social values) of the first-century Mediterranean world that are implicitly embedded in the story Jesus told, social values also not known by the modern reader. These social values were part of the repertoire of the teller and audience of the parable - a shared cultural world of references (Scott 2001:109-117). Social-scientific criticism inter alia focus on this aspect of ancient texts: In this approach texts are seen as products of social systems; therefore, no text can responsibly be interpreted if the social system that produced the text is not taken seriously.

The social values embedded in the Mustard Seed that play a role in the dynamics of the parable are at least the following: What kind of mustard seed is referred to in the parable, and what was their characteristic that may be important for the intent of the parable? Can a mustard seed become a tree? Were birds that flock to trees in an advanced agrarian society perceived by peasants as positive or negative? Was it normal or acceptable to plant mustard seed in a garden? Scott (1989:381; 2001:3546), from a social-scientific perspective, has attended to this important question in his interpretation of the parable. Other scholars that applied this approach to certain aspects of the parable are Crossan (1991:278-279), Oakman (2008:111-117) and Miller (2001:112-116). To these contributions we will return in $\S 4.2$.

\subsubsection{The kingdom of God is like a mustard seed}

The mustard seed was proverbially known for its smallness (see, e.g., Mt 17:20//Lk 17:6; $m$. Niddah 5.2; b. Berakot 31a; $m$. Teharot 8.8; $m$. Nazir 1.5; Lev. Rab. 31; for Hellenistic sources, see Hultgren Hultgren 2000:395), and used as a familiar term to mean the tiniest thing possible (see, e.g., y. Pe'ah 7.4 ; b. Ketubot iiib), but was not the smallest seed as typified by Mark (Funk et al. 1993:194, Jones 1995:326; Scott 1989:377). The seeds of the orchid and cypress, for example, were known to be smaller (Snodgrass 2008:220). The seed of the mustard plant is approximately 1 millimetre in diameter, germinates within 5 days and grows quickly to about 2-3 meters in height. The mustard plant is

an annual herb with large leaves clustered mainly at the base of the plant. Its central stem branches abundantly in its upper part and produce an enormous number of yellow flowers and small, manyseeded linear fruits (Zohary 1982:93). 
The mustard plant thus is a shrub, and not a tree; ${ }^{29}$ its branches are not sturdy enough to support the nests of birds (Reid 2001:104). The plant has a very pungent taste, and oil derived from the plant was used as seasoning in food and for medicinal purposes ${ }^{30}$ (Scott 1989:380). In spite of these properties, the mustard plant was not popular in Palestine. It grew very rapid and aggressive, and spread like a weed or invasive shrub. Because of its tendency to take over, it needed persistent control. ${ }^{31}$

Pliny (Natural History 19.171), as well as the Mishnah, distinguishes three kinds of mustard plants. Of the three kinds in the Mishnah one is wild (laphsân), and the other two domesticated (hardâl and hardâl misri). These three varieties most probably correlates with the three varieties of mustard that today grow in Palestine, namely the brassica nigra (black mustard = hardâl) and sinapis nigra (white mustard = hardâl misri) and the sinapis arvensis (charlock = laphsân; see Oakman 2008:114). According to

29 In antiquity, however, the term $\delta$ ś $\delta \delta \rho o v$ was sometimes used to refer to tall plants, but that does not make the mustard plant a tree (Hultgren 2000:396). Y. Pe'ah 7.4 and $b$. Ketubot iiiib indeed describe the mustard plant as a tree, but they are exaggerations in an attempt to describe the fertility of Israel prior to the destruction of the temple (see Snodgrass 2008:220, $n$ 205). According to Baarslag (1940:426), the mustard plant referred to in the parable is not the sinapis alba, but the salvadore persica that one can find near the Dead Sea and the Sea of Galilee, of which its berries tastes like mustard and can reach a height of 7-8 meters. See, however, the discussion below.

30 According to Pliny (Natural History 20.87), the mustard herb, when pounded with vinegar, can be used a liniment for the stings of serpents and scorpions, and it effectually neutralizes the poisonous properties of fungi. It can be used to cure an immoderate secretion of phlegm, and mixed with hydromel, it can be used as a gargle. Mustard can be chewed for toothache and is very beneficial for all maladies of the stomach. Taken with the food, it facilitates expectoration from the lungs, and, in combination with cucumber seed, helps for asthma and epileptic fits. It has the effect of quickening the senses, effectually clears the head by sneezing, relaxes the stomach, and promotes menstrual discharge and urinary secretions. When beaten up with figs and cumin, it is used as an external application for dropsy. Mixed with vinegar, mustard resuscitates persons who have swooned in fits of epilepsy or lethargy, as well as females suffering from hysterical suffocations. It is also a cure for lethargy, inveterate pains of the chest, loins, hips, shoulders, and, in general, for all deep-seated pains in any part of the body, as well as blisters and indurations of the skin. Combined with red-earth, it helps for alopecia, itch-scabs, leprosy, phthiriasis, tetanus, and opisthotony.

31 "It [mustard] grows entirely wild, though it is improved by being transplanted: but on the other hand when it has once been sown it is scarcely possible to get the place free of it, as the seed when it falls germinates at once" (Pliny, Natural History, 29.54). 
Oakman, the mustard plant referred to in the parable most probably is the brassica nigra, one of the domesticated varieties that could be planted in a garden for its medicinal and herbal qualities. Oakman here is probably correct, since Mark 4:32 and Matthew 13:32 describe the mustard plant in the parable as the "largest of all garden plants" $(\mu \varepsilon \tilde{\zeta} \zeta 0 \nu \pi \dot{\alpha} \nu \tau \omega \nu \tau \tilde{\omega} \nu$ $\lambda \alpha \chi \alpha \dot{\alpha}(\omega \nu)$. But, as stated by Crossan (1991:278), even when one deliberately cultivates the domesticated mustard seed for its medicinal or culinary properties there is an ever present danger that it will destroy the garden.... "The mustard plant ... is, as domesticated in the garden, dangerous and ... deadly".

\subsubsection{The kingdom of the temple is pure, not polluted}

During the Second Temple-period the priestly elite and Pharisees understood God in terms of his holiness as expressed, for example, in Leviticus 19:2 "Be holy because I, the Lord your God, am holy". God's holiness was understood in the way He created. The way God created was to separate and create order. He separated day from night, the days of the week from the Sabbath, birds, animals and fish were created different from one another and only in "pure" forms (no hybrids), land was separated from the sea (the waters), and every living creature were allocated its proper place in creation (e.g., the fish in the water and the birds in the sky). God's creation, in nuce, meant order in terms of place, time, living beings and status (hierarchy). There was a place for everything and everything had its place. God's holiness meant order, and to be holy as God is holy meant that God's order - as set up at creation - had to be respected. In the time of Jesus, the temple (as the axis mundi), the central religious symbol of the Jewish ethnos, personified God's presence and holiness (order). To replicate God's holiness purity laws were put into place. These rules inter alia determined which animals could be sacrificed (no hybrids or animals with defects), which persons were to preside over the sacrifices, who were allowed to take part in these sacrifices (only "pure" Israelites with no bodily defects), and when and where these sacrifices had to take place.

Fundamental to the purity rules was that things that are not alike are not to be mixed. These rules covered areas such as gender (woman shall not wear anything that pertains to a man, nor shall a man put on a woman's garment; Dt 22:5), agriculture (you shall not sow your vineyard with two kinds of seed; Dt 22:9), husbandry (you shall not plow with an ox and an ass together; Dt 22:10) and clothing (you shall not wear mingled stuff, wool and linen together (Dt 22:11). The prohibition to mix things that are not alike is summarized in the purity code of Leviticus as follows: 
You shall keep my statutes. You shall not let your cattle breed with a different kind; you shall not sow your field with two kinds of seed; nor shall there come upon you a garment of cloth made of two kinds of stuff (Lv 19:19).

Separation lead to order and purity, while mixing things not alike meant chaos and pollution. One therefore was not allowed to plant in a garden whatever one liked.

\subsubsection{The kingdom of Rome: A kingdom of taxes, tribute and rents}

First-century Palestine, as part of the Roman Empire, was an advanced agrarian society. All agrarian societies were aristocratic in character, divided into the haves (rulers) and the have-nots (the ruled). The ruling class (elite) comprised of only 1 to 2 percent of the population and lived in the cities while the rest of the population, the peasants (the ruled) lived in rural areas (Fiensy 2007:39). The elite ruled by hereditary control of the empire's primary recourses of land and labour, and controlled most of the wealth (one-half up to two-thirds) by controlling the land, its produce and the peasants whose labor created the produce. As such, the elite shaped

the social experience of the empire's inhabitants, determined the 'quality' of life, exercised power, controlled wealth, and enjoyed high status (Carter 2006:3; see also Hanson \& Oakman 1998:69).

Control over the land, its yield, its distribution, and its cultivators were exercised by extracting taxes, tribute and rents - an act of domination that subordinated the peasants against their will. The peasantry was exposed to three levels of tribute taking (see Oakman 1986:65). The Roman tribute consisted of two basic forms: the tributum soli (land tax) and the tributum capitis (poll tax). Next in line in Galilee was Herod Antipas together with the Herodian aristocracy centered in Sepphoris and Tiberius. Antipas collected tribute especially to support his rule and to finance his extravagant building projects (the building of Tiberius and the rebuilding of Sepphoris). Finally, the temple aristocracy also took their share in the form of tithes and offerings to support the temple as well as Roman rule. Even the peasants of Galilee were subjected to this demand, although they lived outside the jurisdiction of Judaea. In short: Rome assessed its tribute and then left Herod and the temple elite free to exploit the land to whatever degree they saw fit, "a pattern often found in aristocratic empires and colonial powers" (Herzog 2005:52). 
Although there is some debate on the precise amount of tribute and taxes the peasantry were subjected to, most estimates run from 20 to 35 percent. The appropriation of the so-called surplus of the harvest already left the peasant with nothing more than a subsistence living, from which this percentage of tribute and taxes was deducted. This left the peasantry in a situation where their level of subsistence functioned in a very narrow margin (see Fiensy 1991:103; Herzog 2005:53). For the kingdom of Rome, however, the land and its yield was life. No or smaller harvests meant less "surplus of the land" and less income in taxes. For Rome, this meant a slow death.

\subsection{Reading the parable: Luke 13:18-19}

Before presenting a social-scientific reading the Mustard Seed using what have been said above about the kingdoms of God, the Temple and Rome as interpretative keys, two initial and necessary remarks to set the scene for what to follow. First, the Mustard Seed is not a parable of growth or contrast that envisages an apocalyptical eschatological kingdom. The tradition behind the Mustard Seed as being a parable of growth and accordingly a parable about the eschatological kingdom of God is Mark; by redactionally introducing the smallest/largest-comparison into the parable, the door was opened to interpret the Mustard Seed as depicting an eschatological kingdom - a kingdom that will realise somewhere in future. Luke 13:18-19, the version of the parable that is most probably the closest to earliest Jesus-tradition - simply does not contain the smallest/largest comparison. Also, a serious case can be made that Jesus, in his parables, pictured the kingdom as a present reality (see Van Eck 2009:315-316).

Second, the Mustard Seed does not play into Old Testament imagery by means of the symbols of the mighty cedar of Lebanon as a metaphor for a towering empire (Ezk 17:22-23) and the apocalyptic tree of Daniel 4:12 and 20-22. Would first-century illiterate peasants, when they heard a parable about the kingdom of God that is like a mustard seed that turns into a tree have connected the dots between the tree and the imagery in the Old Testament about the cedar of Lebanon and Daniel's apocalyptic tree? In the scribal tradition and the synagogue, where Old Testament texts were studied by some through the lens of the Jesus-event, this was possible; but most probably not for peasants tilling the soil trying to survive exploitative circumstances raised above mere subsistence living. Even in a scribal tradition this so-called imagery in the parable can be questioned. In Ezekiel 17 and 31, and Daniel 4, the mighty cedar represents the enemies of Israel. "The metaphor is that God brings low the powerful empires of Babylon and Egypt that once stood proudly like tall cedars" (Reid 2001:105). Would 
one compare the kingdom of God with other known despised kingdoms? As put by Reid (2001:105): "When Israel is the small sprig become a lofty cedar ... can it be exempt from such humbling?" Also, if the kingdom of God is like a lofty cedar, in spite of its small beginning, is the kingdom of God not exactly like the kingdom of Rome? Miller (2001:113) answers this in the positive:

In this respect the kingdom of God embodies the same values as the kingdom of Rome, which grew from a small town into a worldwide empire.

The parable then asserts that "God is on the side of the victor, exactly the lesson Rome wanted to teach its subjects" (Miller 2001:113). If this is what the parable intended to communicate, peasants would have heard it, to borrow the words of Rohrbaugh, as a "text of terror". If the kingdom of God was exploitative and domineering as the kingdoms of Rome and the Temple, it was not something a peasant wanted to hear.

What then was Jesus' intent with the Mustard Seed? In the parable Jesus does not use the mustard seed as a comparison for the kingdom because of its smallness; ${ }^{32}$ the mustard seed is used because of its characteristics that were well known by first-century Galilean peasants, the first hearers of the parable. The kingdom is like a mustard seed that, when it becomes a plant, can be put to good use in terms of its culinary and medicinal properties. But watch out: although it is an annual, it reseeds itself, and keeps on reseeding. It comes up again and again. You cannot stop it, and not really erase it, the mustard plant grows very rapid and aggressive, and spreads like a weed or invasive shrub. Because of its tendency to take over, it needs persistent control. But, as long as it grows in the wild, this is not really a problem. This is the kingdom of God, like a mustard plant that can be put to good use; nothing new or extraordinary thus far.

But then a twist: the kingdom of God is not only like a mustard seed, but like a mustard seed that is planted in a garden. Someone is looking for trouble, for at least two reasons. First of all, the planting of a mustard seed in a garden was prohibited according to the purity rules of the kingdom of

32 See Miller (2001:113), who makes the following remark in this regard: "Other examples (than the mustard seed - EvE) could have served just as well. After all, every plant starts from a seed. The mustard is actually an uninspiring example for a lesson about growth. If the object is to contrast inconspicuous origins with impressive results, why single out a lowly mustard bush? Why not a tree: the rugged olive, or the stately palm? Better yet, why not the strong and lofty cedar of Lebanon, a tree that symbolizes world empires in Ezekiel and Daniel?" 
the Temple. In an ordered society, like a garden, everything had its place and there was a place for everything; things that are not alike (different) are not to be mixed (Lv 19:19). Separation lead to order and purity, while mixing things not alike meant chaos and pollution. The later elaboration in the Mishnah on this purity rule is clear: the mustard seed constitutes a mixed kind ( $m$. Kil 1.5), ${ }^{33}$ and therefore it was strictly prohibited to plant a mustard seeds in a garden ( $m$. Kil. 3.2; ${ }^{34}$ Scott 2001:35-46; 2007:101). By planting the mustard seed in the garden, the man thus violates the law of diverse kinds (Scott 1989:381), and pollutes the garden. The garden is unclean, a symbol of chaos. As a metaphor for the kingdom, the kingdom of God is thus polluted and unclean. An ordered kingdom has been replaced by a chaotic and polluted kingdom. But not only replaced; it has been taken over by a unclean "mixed kind" that grows wild, is invasive and difficult, if at all possible, to control. ${ }^{35}$ As such, the kingdom of God is dangerous and deadly. In time it will take over the ordered and unpolluted garden (ordered society) of the kingdom of the Temple. Order is turned into chaos; the kingdom of God is taking over the kingdom of the Temple.

The mustard seed, however, is also taking over the kingdom of Rome. In what sense is it taking over? This is the surprise in the parable, typical of the parables of Jesus. ${ }^{36}$ The mustard seed does not grow into a garden shrub whose branches would scarcely support a nest for birds much less

33 "Although the long radish and the round radish, mustard and wild mustard, the Greek gourd and the Egyptian or bitter gourd are like to each other, they are accounted Diverse Kinds" (Danby 2011:29).

34 "Not every kind of seed may be sown in a garden-bed, but any kind of vegetable may be sown therein. Mustard and small beans are deemed a kind of seed and large beans a kind of vegetable" (Danby 2011:31).

35 As Crossan (1991:278) puts it: "[E]ven when one deliberately cultivates the domesticated mustard seed for its medicinal or culinary properties there is an ever present danger that it will destroy the garden.... The mustard plant ... is, as domesticated in the garden, dangerous and ... deadly".

36 According to Crossan (1992:48), the seed turning into a tree is the question of the parable. This is only the case when one thinks of a mustard seed turning into a tree in terms of botanical or horticultural properties, or see the tree as a "biological misfit" (Scott 2001:35-46). The seed turning into a tree is the surprise in the parable - part of the narrative artistry of the parable - as we have surprises in almost all of Jesus' parables: a Samaritan becomes the hero when somebody is in dire straits (Lk 10:30-35); a patron does not exploit day laborers by paying them all the same wage (Mt 20:1-15), a father does not chastise his prodigal son but welcomes him back (LK 15:11-32); a patron cancels the huge debt of one of his slaves (Mt 18:23-34); an elite invites the wrong people to a wedding (Lk 14:16-23); an owner does not take up his right to kill his tenants because of their violent actions (Thom 65); and shepherd leaves ninety nine of 
offer any significant shade. No, in turns into a tree with branches strong enough in which birds can roost and nest; a tree in which they can make a home. And what do these birds do? As pesky intruders of cultivated lands, the natural enemies of the sown (Oakman 2008:116), they feed of the land by plundering the cultivated fields. From their safe haven they take from the kingdom of Rome by plundering its base of taxation; the smaller the harvest and the surplus of the land, the less tax have to be paid.

Read from the above perspective, the Mustard Seed questions religious respectability as proposed by the kingdom of the Temple (see Miller 2001:113-114) and undermines the imperial interests of the kingdom of Rome. The parable tells of a kingdom where God is associated with uncleanness, where boundaries are porous, and where separation cannot and should not be maintained. The kingdom of God spreads effortlessly, takes over and pollutes, bringing along its unwelcome inhabitants that subverts the kingdoms of the Temple and Rome. The mustard seed indeed has medicinal properties; it can heal the causes of exclusive, exploitative and domineering kingdoms.

\section{A PARABLE OF JESUS?}

The parable, as interpreted above, has all the earmarks of a Jesus parable. Typical of Jesus' parables, it cuts against the grain of the exploitative world of first-century Palestine, and most probably represents the earliest layer of the historical Jesus tradition. It resonates with Jesus' attitude towards the temple purity system (exclusivity) and the negative impact imperial Rome had in the lives of the peasantry. In terms of the criteria of early, multiple and independent attestation and coherence the parable displays typical values that Jesus supported.

With regards to Jesus' critique on the temple's purity system, the parable inter alia parallels Jesus' sayings in Mark 7:14-15//Matthew 15:10$11 / /$ Thomas 14:5 (it is not what goes in that defiles, but what goes out). ${ }^{37}$ The values in the parable are also paralleled in other Jesus parables, either in a positive or negative way. In the parable of the Leaven (Q 13:20-21 [Mt 13:33/Lk 13:20-21]//Thom 96:1-2) the kingdom is also described as

his sheep unprotected to go and look for one that is lost instead of turning to violence (Lk 15:4-6).

37 See Funk (et al. 1993:69): "The aphorism ... is a categorical challenge to the laws governing pollution and purity. Since the saying need not be taken entirely literally ... it can also be made to apply to other forms of pollution .... it challenges the everyday, the inherited, the established, and erases social boundaries taken to be sacrosanct". 
being "unclean" or "impure". Like the host in the parable of the Great Feast (Lk 14:16a-23), Jesus regularly associated with the so-called "impure" and ate with the so-called "sinners" of his day. In this parable Jesus also questions honor and status as pivotal social values of his time. As many of Jesus' other sayings, the Mustard Seeds subverts the values of both the kingdoms of the Temple and Rome. As in many of Jesus' parables, the focus of Luke 13:18-19 is the expansive power of the kingdom of God that is able to subvert or invert the exploitative social system of his day (see also Kloppenborg 2000:391-392).

\section{BIBLIOGRAPHY}

ARNot, W.

1872. The parables of our Lord. New York: Nelson and Sons.

BAARSLAG, D.J.

1940. Gelijkenissen des Heren. Tweede Deel. Baar: Bosch \& Keuning N.V.

Beasley-Murray, G.R.

1986. Jesus and the kingdom of God. Grand Rapids: William B. Eerdmans Publishing Company.

Blomberg, C.L.

2004. Preaching the parables: From responsible interpretation to powerful proclamation. Grand Rapids: Baker Academic.

BOICE, J.M.

1983. The parables of Jesus. Chicago: Moody Press.

BOUCHER, M.I.

1981. The parables. Wilmington: Michael Glazier Inc. New Testament Message 7.

Brouwer, A.M.

1946. De gelijkenissen. Leiden: A.W. Sijthoff's Uitgeversmaatschappij N.V.

Bruce, A.B.

1886. The parabolic teaching of Christ: A systematic and critical study of the parables of our Lord. New York: Hodder \& Stoughton.

Bugge, C.A.

1903. Die Haupt-Parabeln Jesu. Griessen: J. Rickersche Verlagsbuchhandlung.

Bultmann, R.

1963. History of the synoptic tradition. Oxford: Blackwell.

BUTTRICK, D.

2000. Speaking in parables: A homiletical guide. Louisville: Westminster John Knox Press. 
CAPON, R.F.

1985. The parables of the kingdom. Grand Rapids: William B. Eerdmans Publishing Company.

Carter, W.

2006. The Roman Empire and the New Testament: An essential guide. Nashville: Abingdon Press.

CotTer, W.J.

1992. The parables of the mustard seed and leaven: Their function in the earliest stratum of Q. Toronto Journal of Theology 8:37-51.

Crossan, J.D.

1973. The seed parables of Jesus. Journal of Biblical Literature 92:244-266.

1991. The historical Jesus: The life of a Mediterranean Jewish peasant. San Francisco: HarperSanFrancisco.

1992. In parables: The challenge of the historical Jesus. Sonoma: Polebridge Press.

DAHL, N.A.

1976. The parables of growth. Minneapolis: Augsburg Press.

DANBY, $\mathrm{H}$.

2011. The Mishnah: Translated from the Hebrew with introduction and brief explanatory notes. Peabody: Hendrickson Publishers.

Davies, W.D. \& Aluison, D.C.

1997. A critical and exegetical commentary on the gospel according to Saint Matthew. Vol 2. Edinburgh: T\&T Clark. ICC.

DiBelius, M.

1971. From tradition to gospel. Transl. by B.L. Woolf. London: James Clarke.

Dodd, C.H.

1961. The parables of the kingdom. New York: Charles Scribner's Sons.

DONAHUE, J.R.

1988. The gospel in parable: Metaphor, narrative and theology in the Synoptic gospels. Philadelphia: Fortress Press.

DRURY, J.

1985. The parables in the gospels: History and allegory. New York: Crossroads.

DUPONT, J.

1975. Le couple parabolique du sénevé et du levain, Mt 13,31-33; Lc 13,18-21. In: G. Strecker (ed.), Jesus Christ in Historie und Theologie: Neutestamentliche Festschrift für Hans Conzelmann zom 60. Geburtstag (Tübingen, Mohr-Siebeck), pp. 331-345 
Fiensy, D

1991. The social history of Palestine in the Herodian period: The land is mine. New York: Edwin Mellen Press.

2007. Jesus the Galilean: Soundings in a first century life. Piscataway: Gorgias Press.

Fleddermann, H.T.

1989. The mustard seed and the leaven in Q, the Synoptics, and Thomas. In: D.J. Lull (ed.), Society of Biblical Literature 1989 Seminar Papers (Atlanta, Scholars Press), pp. 216-236.

FRANCE, R.T.

2002. The gospel of Mark: A commentary on the Greek text. Grand Rapids: William B. Eerdmans Publishing Company. NIGTC.

Fuchs, E.

1960. Zur Frage nach dem historischen Jesus. Tübingen: JCB Mohr.

Funk, R.W.

1973. The looking-glass tree is for the birds. Interpretation 27:3-9.

2006. The looking-glass tree is for the birds. In: B.B. Scott (ed.), Funk on parables: Collected essays (Santa Rosa, Polebridge Press), pp. 113-120.

Funk, R.W., Hoover, R.W. \& The Jesus Seminar. 1993. The five gospels: The search for the authentic words of Jesus. New York: Macmillan.

GäBeL, G.

2007. Mehr Hoffnung wagen (Vom Senfkorn) - Mk 4,30-32. In: R. Zimmermann (Hrsg.), Kompendium der Gleichnisse Jesu (Munich, Gütersloher Verlagshaus), pp. 327-336.

Gladden, W.

1883. Things new and old. In: A.H. Smythe (ed.), Discourses of Christian truth and life (Ohio, Columbus), pp. 3-27.

GRÄSSER, E.

1960. Das Problem der Parusieverzögerung in den synoptischen Evangelien und in der Apostelgeschichte . Berlin: Töpelmann. BZNW 22.

Groenewald, E.P.

1973. In gelykenisse het Hy geleer. Kaapstad: .G. Kerk-Uitgewers.

GUNDRY, R.

1993. Mark: A commentary on his apology for the cross. Grand Rapids: William

B. Eerdmans Publishing Company.

Hanson, K.C. \& OAKMAN, D.E.

1998. Palestine in the time of Jesus: Social structures and social conflicts. Minneapolis: Fortress Press.. 
HEDRICK, C.W.

1994. Parables as poetic fictions: The creative voice of Jesus. Peabody: Hendrickson Publishers.

HEIL, J.P.

1993. Reader-response and the narrative context of the parables about growing seed in Mark 4:1-34. CBQ 54:278-286.

HERZOG, W.R.

2005. Prophet and teacher: An introduction to the historical Jesus. Louisville: Westminister John Knox Press.

HULTGREN, A.J.

2000. The parables of Jesus: A commentary. Grand Rapids: William B. Eerdmans Publishing Company.

HUNTER, A.M.

1971. The parables: Then and now. Philadelphia: Westminster Press.

1976. Interpreting the parables. London: SCM Press Ltd.

JEREMIAS, J.

1972. The parables of Jesus. London: SCM Press Ltd.

JONES, I.H.

1995. The Matthean parables: A literary and historical commentary. Leiden: E.J. Brill. Supplements to Novum Testamentum. Volume LXXX.

JONES, P.R.

1999. Studying the parables. Macon: Smyth \& Helwys.

JÜLICHER, A.

1910. Die Gleichnisreden Jesu. Tübingen: JCB Mohr.

JÜNGEL, E.

1962. Paulus und Jesus: Eine Untersuchung zur Präziserung der Frage nach dem Ursprung der Christologie. Tübingen: JCB Mohr. Hermeneutische Untersuchungen zur Theologie. HUTh 2.

$\mathrm{KEACH}, \mathrm{B}$.

1978. Exposition of the parables in the Bible. Grand Rapids: Kregel Publications.

KENDALL, R.T.

2006. The parables of Jesus: $A$ guide to understanding and applying the stories Jesus told. Grand Rapids: William B. Eerdmans Publishing Company.

KILGALLEN, J.J.

2008. Twenty parables of Jesus in the gospel of Luke. Rome: Editrice Pontificio Instituto Biblico. Subsidia Biblica 32. 
KISTEMAKER, S.J.

1980. The parables: Understanding the stories Jesus told. Baker Books. Grand Rapids.

KLOPPENBORG, J.S.

1988. Q parallels: Synopsis, critical notes \& concordance. Sonoma: Polebridge Press.

2000. Excavating Q: The history and setting of the Sayings Gospel. Minneapolis: Fortress Press.

KÜMmeL, W.G.

1957. Promise and fulfilment: The eschatological message of Jesus. Transl. by

D.M. Barton. Naperville: Allenson. SBT 23.

LAMBRECHT, J.

1983. Once more astonished: The parables of Jesus. New York: Crossroad.

LANG, G.H.

1955. Pictures and parables. Londen: The Paternoster Press.

LIEBENBERG, J.

2000. The language of the kingdom and Jesus: Parable, aphorism, and metaphor in the sayings material common to the Synoptic tradition and the Gospel of Thomas. Berlin: Walter de Gruyter.

LOCKYER, $\mathrm{H}$.

1963. All the parables of the Bible. Grand Rapids: Zondervan.

Louw, J.P., \& NIDA, E.A. (Eds.)

1988. Greek-English lexicon of the New Testament based on semantic domains. Vol. 1. Domains. Goodwood: National Book Printers..

Luz, U.

1990. Das Evangelium nach Matthäus. vol. 2. Mt 8-17. Zurich: Benziger Verlag. EKKNT 1/3.

Manson, T.W.

1949. The sayings of Jesus. Londen: SCM Press.

MARcus, J.B. 1986. The mystery of the kingdom of God. Atlanta: Scholars Press. SBLDS 90.

2000. Mark 1-8: A new translation with introduction and commentary. New York: Doubleday. AB 27.

MiLleR, R.J.

2001. Is the apocalyptic Jesus history? In: K. Armstrong, D. Cupitt, R.W. Funk, L. Geering, J.S. Spong \& Fellows of the Jesus Seminar. The once \& future faith. (Santa Rosa, Polebridge Press), pp. 101-116. 
Morgan, G.C.

1953. The parables and metaphors of our Lord. Londen: Marshall, Morgan \& Scott, Ltd.

Mussner, F. 1960. 1Q Hodajoth und das Gleichnis vom Senfkorn (Mk 4:30-32 Par.). Biblische Zeitschrift 4:128-130.

OAKMAN, D.E. 1986. Jesus and the economic questions of his day. New York: Edwin Mellen Press.

2008. Jesus and the peasants. Eugene: Cascade Books. Matrix: The Bible in Mediterranean context.

2012. The political aims of Jesus. Minneapolis: Fortress Press.

PATTERson, S.J.

1993. The Gospel of Thomas and Jesus. Sonoma: Polebridge Press.

Patterson, S.J., Bethge, H.-G. \& Robinson, J.M. 2011. The fifth gospel: The gospel of Thomas comes of age. New York: T \& T Clark.

Pelikan, J., Oswald, H.C. \& Lehmann, H.T. (Eds.) 1987. Martin Luther's works. Vol. 54. Philadelphia: Concordia Publishing House..

Perkins, P. 1981. Hearing the parables of Jesus. New York: Paulist Press.

Perrin, N.

1971. The Christology of Mark: A study in methodology. JR 51:173-187.

Polag, A.

1979. Fragmenta Q: Textheft zur Logienquelle. Neukirchen- Vluyn: Neukirchener Verlag.

Rauschenbush, W. 1950. A gospel for the social awakening: Selections from the writings of Walter Rauschenbush. New York: Association Press.

REID, B.E.

2001. Parables for preachers: The gospel of Matthew. Collegeville: The Liturgical Press.

SCHARLEMANN, M.H.

1979. The parables of the leaven and the mustard seed: A suggested methodological model. In: J. Reumann (ed.), Studies in Lutheran hermeneutics (Philadelphia, Fortress Press), pp. 335-354. 
Scotr, B.B.

1989. Hear then the parable: A commentary on the parables of Jesus. Fortress Press: Minneapolis.

2001. Re-imagine the world: An introduction to the parables of Jesus. Santa Rosa: Polebridge Press.

2007. The reappearance of parables. In: E.F. Beutner. (ed.), Listening to the parables of Jesus Jesus Seminar Guides, Volume 2. (Santa Rosa, Polebridge Press), pp. 95-119.

SCHIPPERS, $R$.

1962. Gelijkenissen van Jezus. Kampen: J. H. Kok N.V.

SCHWEITZER, A.

1963. The kingdom of God in the teaching of Jesus. Philadelphia: Westminster Press.

SMITH, B.T.D.

1937. The parables of the synoptic Gospels: A critical study. Cambridge: Cambridge University Press.

SNODGRASS, K.R.

2008. Stories with intent: A comprehensive guide to the parables of Jesus. Grand Rapids: William B. Eerdmans Publishing House.

Stein, R.H.

1981. An introduction to the parables of Jesus. Philadelphia: The Westminster Press.

StREeTER, B.H.

1930. The four gospels: A study of origins. New York: St. Martin's Press.

Torrance, D.W. \& Torrance, T.F. (Eds.)

1972. Calvin's commentaries: A harmony of the gospels Matthew and Luke. Vol. 3. Transl. by A.W. Morrison. Edinburgh: Saint Andrews Press.

VAN ECK, E.

2009. Interpreting the parables of the Galilean Jesus: A social-scientific approach. HTS Teologiese Studies/Theological Studies 65(1):310-321.

WEISS, J.

1900. Die Predicht Jesu vom Reiche Gottes. Götiingen: Vandenhoeck \& Ruprecht.

WeNHAM, D.

1989. The parables of Jesus: Pictures of a revolution. Londen: Hodder \& Stoughton. The Jesus Library.

Westermann, C.

1990. The parables of Jesus in the light of the Old Testament. Transl. by F.W. Golka \& A.H.B. Logan. Edinburgh: T\&T Clark. 
WieRzBickA, A. 2001. What did Jesus mean? Explaining the Sermon on the Mount and the parables in simple and human concepts. Oxford: Oxford University Press.

WILLS, L.M.

2011. The gospel according to Mark. In: A.-J. Levine, \& M.C. Brettler, (eds.), The Jewish annotated New Testament: New Revised Standard Version Bible translation (New York, Oxford University Press Inc), pp. 55-95.

ZOHARY, M.

1982. Plants of the Bible. Cambridge: Cambridge University Press.

\section{CLASSICAL WORKS CONSULTED}

Apostolic Constitutions (Book III).

[s.a.] [Online.] Retrieved from: http://www.newadvent.org/fathers/07153.htm [2013, 1 October].

Augustine Of Hippo

[s.a.] Contra Faustum, Book XXII. [Online.] Retrieved from: http://www. newadvent.org/fathers/140622.htm [2013, 1 October].

\section{BASIL The GREAT}

373. Treatise De Spiritu Sancto. [Online.] Retrieved from: http://www. catholicculture.org/culture/library/fathers/view.cfm?recnum $=2544 \quad[2013,1$ October].

Clement Of Alexandria

[s.a.] The Instructor [Paedagogus.]. [Online.] Retrieved from: http://www. catholicculture.org/culture/library/fathers/view.cfm?recnum=1659 $[2013,1$ October].

[s.a.] Fragments of Clemens Alexandrinus. [Online.] Retrieved from: http:// www.catholicculture.org/culture/library/fathers/view.cfm?recnum $=1649$ [2013, 1 October].

\section{Gregory Of Nazianzus}

[s.a.] Oration XLII. [Online.] Retrieved from: http://www.catholicculture.org/ culture/library/fathers/view.cfm?recnum=2452 [2013, 1 October].

IRENAEUS

[s.a.] Fragments from the Lost Writings of Irenaeus. [Online.] Retrieved from http://www.catholicculture.org/culture/library/fathers/view.cfm?recnum=1625 [2013, 1 October].

JEROME

397. Letter LXVI: TO Pammachius. [Online.] Retrieved from: http://www. catholicculture.org/culture/library/fathers/view.cfm?recnum $=2368 \quad[2013,1$ October]. 
John Chrysostom

[s.a.] Homilies 11-23 on the Epistle to the Hebrews [Online.] Retrieved from: http://www.catholicculture.org/culture/library/fathers/view.cfm?recnum=2051 [2013, 1 October].

PLINY

[s.a.] The Natural History. [Online.] Retrieved from: http://www.perseus.tufts. edu/hopper/text?doc=Plin.+Nat.+toc [2013, 1 October].

TeRTULLIAN

[s.a.] The Five Books against Marcion, Books IV-V. [Online.] Retrieved from: http://www.catholicculture.org/culture/library/fathers/view.cfm?recnum=1665 [2013, 1 October].

Keywords

Social-scientific criticism

Parable of the Mustard Seed

Kingdom of God

Eschatology

Imperial interests
Trefwoorde

Sosiaalwetenskaplike analise

Gelykenis van die mosterd saad

Koninkryk van God

Eskatologie

Imperiale belange 